Original Contribution

\title{
BLOOD CONCENTRATION OF HEAVY METALS AMONG ENVIRONMENTALLY EXPOSED RESIDENTS OF STARA ZAGORA MUNICIPALITY (BULGARIA)
}

\author{
P. Gidikova ${ }^{1^{*}}$, G. Sandeva ${ }^{1}$, R. Deliradeva ${ }^{1}$, G. Prakova ${ }^{2}$, M. Platikanova ${ }^{1}$ \\ ${ }^{1}$ Section of Hygiene and Medical Ecology, Faculty of Medicine, Trakia University, Stara Zagora, Bulgaria \\ ${ }^{2}$ Department of Internal Diseases, Faculty of Medicine, Trakia University, Stara Zagora, Bulgaria
}

\begin{abstract}
PURPOSE: The aim of this study was to reveal whether people living in the villages Zmeyovo and Borilovo (where the highest rates of excessive and borderline heavy metal concentrations in plants had previously been registered) are at higher risk of combined exposure to lead, cadmium and nickel. METHODS: Blood levels of these heavy metals were studied in groups of 17 nonsmokers ( 9 females and 8 males) from each of the studied villages, and in a control group from a remote mountain village by atomic absorption spectrometry. RESULTS: The mean blood levels of lead $(56.48$ and $19.93 \mu \mathrm{g} / \mathrm{dL})$ and cadmium $(3.36$ and $0.95 \mu \mathrm{g} / \mathrm{L})$ for Zmeyovo and Borilovo respectively were significantly higher than those in the control group. Mean nickel blood concentration was higher than controls for Zmeyovo only $(2.17 \mu \mathrm{g} / \mathrm{dL})$. Statistically significant correlations among blood levels of lead, cadmium and nickel were found, which suggested combined exposure. The mean concentrations of all the heavy metals studied were relatively higher than available data for the general population in Europe. CONCLUSIONS: The study showed an increased exposure to heavy metals among residents of the region. Implementation of screening programs, especially for children and young adults, is therefore advised.
\end{abstract}

Key words: environmental exposure, lead, cadmium, nickel, blood

\section{INTRODUCTION}

Stara Zagora municipality is located in the central part of southern Bulgaria (N 42 $25^{\prime}$, E $\left.25^{\circ} 37^{\prime}\right)$. The municipality covers an area of $1019 \mathrm{~km}^{2}$ on the southern slopes of the mountain Central Sarnena Gora with an average altitude of 240 meters. The total population of the municipality is 157,000 , of which 136,000 live in the town of Stara Zagora and 21,000 inhabit the 50 surrounding villages.

Known potential sources of environmental pollution in the region are the coal power complex Maritsa Iztok (the biggest in Southeastern Europe) with surface coal mines and three power stations, and the military proving ground Zmeyovo. Maritsa Iztok

\footnotetext{
*Correspondence to: Pavlina Gidikova, Department of Hygiene and Medical Ecology, Faculty of Medicine, 11 Armeyska Str, 6000 Stara Zagora, Bulgaria, Phone number: +35942664329, E-mail address: pgidikova@yahoo.com
}

Complex is located $40 \mathrm{~km}$ southeast of Stara Zagora town and covers $240 \mathrm{~km}^{2}$, while the military proving ground is situated $7 \mathrm{~km}$ northwest, with $95.6 \mathrm{~km}^{2}$ area at $420 \mathrm{~m}$ altitude. In addition, a highway, some major roads and a major transport junction are found in the region. These sources cause significant environmental pollution in the region, especially during unfavorable meteorological conditions.

Government institutions perform routine yearround monitoring of air quality to determine the levels of a standard set of atmospheric pollutants, according to the Bulgarian Clean Air Act (1). The concentrations of lead, cadmium and nickel in the air have been monitored since 2008 at Ostra Mogila village (N 42²8'11", E25 $27^{\prime} 50^{\prime \prime}, 430 \mathrm{~m}$ altitude) by an automated differential optic absorption spectroscopy system. According to the National Report on the State and Protection of the Environment 2014 (2) all registered mean annual concentrations were regularly found to be under the limits fixed in the 
national regulations $(3,4)$. Heavy metal levels in the drinking water are measured once a year by the Regional Health Inspection - Stara Zagora. All lead, cadmium and nickel concentrations in drinking water from the region were also below the regulation limits (5).

Heavy metal levels in soil, groundwater and plants growing in the region are not routinely monitored. In recent years (2005, 2007 and 2008) some tests on heavy metals in plants, soil, and groundwater were conducted by UIS Umweltinstitut Synlab GmbH Stuttgart, Germany on behalf of the Municipality of Stara Zagora. 141 plant samples (mushrooms, walnuts, grapes, apples, pears, tomatoes, cabbage) from nine different villages and one location within the town's limits were tested for nine metals lead, cadmium, nickel, zinc, arsenic, chromium, copper, manganese, and iron. Among all 987 obtained results, concentrations exceeding the maximum levels established in national and European legislation (6) were registered in 39 samples (4\%), and borderline concentrations in $67(6.8 \%)$. The highest rate of concentrations exceeding the maximum permissible levels was recorded in two villages situated northwest of Stara Zagora - Borilovo (9.2\% excessive and $22.9 \%$ borderline concentrations) and Zmeyovo ( $7.4 \%$ and $14.7 \%$, respectively), mainly for lead, cadmium and nickel (7). Testing of soil and groundwater samples taken only once in 2008 from six villages revealed no excessive levels of heavy metals, compared with the permissible levels $(8,9)$.

Until the current study, no blood or other bodily fluid samples had been taken from local residents, resulting in insufficient data on the population's exposure to heavy metals. Although the atmospheric levels of heavy metals are currently low, they are persistent in the environment and are subject to bioaccumulation in food chains $(10,11)$. The general population is exposed to lead, cadmium and nickel mainly via food consumption and tobacco smoking (1017), hence there exists a potential risk of higher cumulative exposure.

The aim of this study was to reveal whether people living in the villages Zmeyovo and Borilovo (where the highest rates of excessive and borderline heavy metal concentrations in plants were registered) are at higher risk of cumulative exposure to lead, cadmium and nickel.

\section{MATERIALS AND METHODS}

Concentrations of cadmium, lead and nickel in blood samples are traditionally used as biomarkers of environmental exposure (18-20). Levels of lead, cadmium and nickel in whole blood of residents of the villages Zmeyovo and Borilovo, and a control group were examined in 2013. The group from Zmeyovo $(n=17)$ consisted of nine females and eight males with mean age of $63.5 \pm 8.7$ years. The group from Borilovo $(n=17)$ also consisted of nine females and eight males with mean age of $68.3 \pm 11.9$ years. For a control village was chosen the village of Kolyo Marinovo, situated in Sredna Gora mountain outside of Stara Zagora municipality, far from significant pollution sources. The control group $(n=16)$ included eight males and females each with mean age of $67.7 \pm 8.5$ years.

There was no significant difference in the average age of donors. All participating subjects had been permanent residents of the studied villages for at least 10 years. Donors were selected to be non-smokers, since smoking contributes to a significant intake of heavy metals (20-22). All blood donors gave their written informed consent.

For assessing heavy metal concentrations $5 \mathrm{~mL}$ venous blood was taken from each subject in 6 $\mathrm{mL}$ vacutainers with K3EDTA. The analysis was performed at the Research Laboratory of the Faculty of Agriculture, Trakia University. After microwave digestion of samples in Multiwave 3000 the heavy metal concentrations were measured by atomic absorption spectrometer 800 Analyst AAS, Perkin Elmer, operating with flame or graphite tubes with an additional injection hydride system. The methodologies for each metal were validated and monitored.

Data analysis was performed using Statsoft Statistica v. 8. T-test for independent variables was used for comparison of heavy metal levels in blood between exposed and control groups. Correlations between blood levels of lead, cadmium and nickel were found by regression analysis.

\section{RESULTS}

Statistical analysis of results obtained showed the highest mean blood lead level $(\mathrm{BPb})$ among the residents of Zmeyovo village $-56.48 \pm 35.11$ $\mu \mathrm{g} / \mathrm{dL}$. It was significantly higher than the mean 
$\mathrm{BPb}$ for Borilovo $-19.93 \pm 11.81 \mu \mathrm{g} / \mathrm{dL}$ and the control village - 13.15 \pm 5.11 (Figure 1). The mean $\mathrm{BPb}$ in Borilovo was also significantly higher than that in the control village. In 15 resident ( 8 females and 7 males) among all 17 investigated from Zmeyovo and in 3 ( 2 females and 1 males) from Borilovo blood lead levels were above $20 \mu \mathrm{g} / \mathrm{dL}$ - recommended as threshold for occupationally non-exposed adults
(12). Moreover, in five women and five men from Zmeyovo BPbs exceeded the level of 40 $\mu \mathrm{g} / \mathrm{dL}$ over which signs of mild lead intoxication could be manifested (14). Only one woman in Borilovo had a similarly elevated $\mathrm{BPb}$. In comparison, no subject from the control village exhibited a $\mathrm{BPb}$ over the recommended 20 $\mu \mathrm{g} / \mathrm{dL}$.

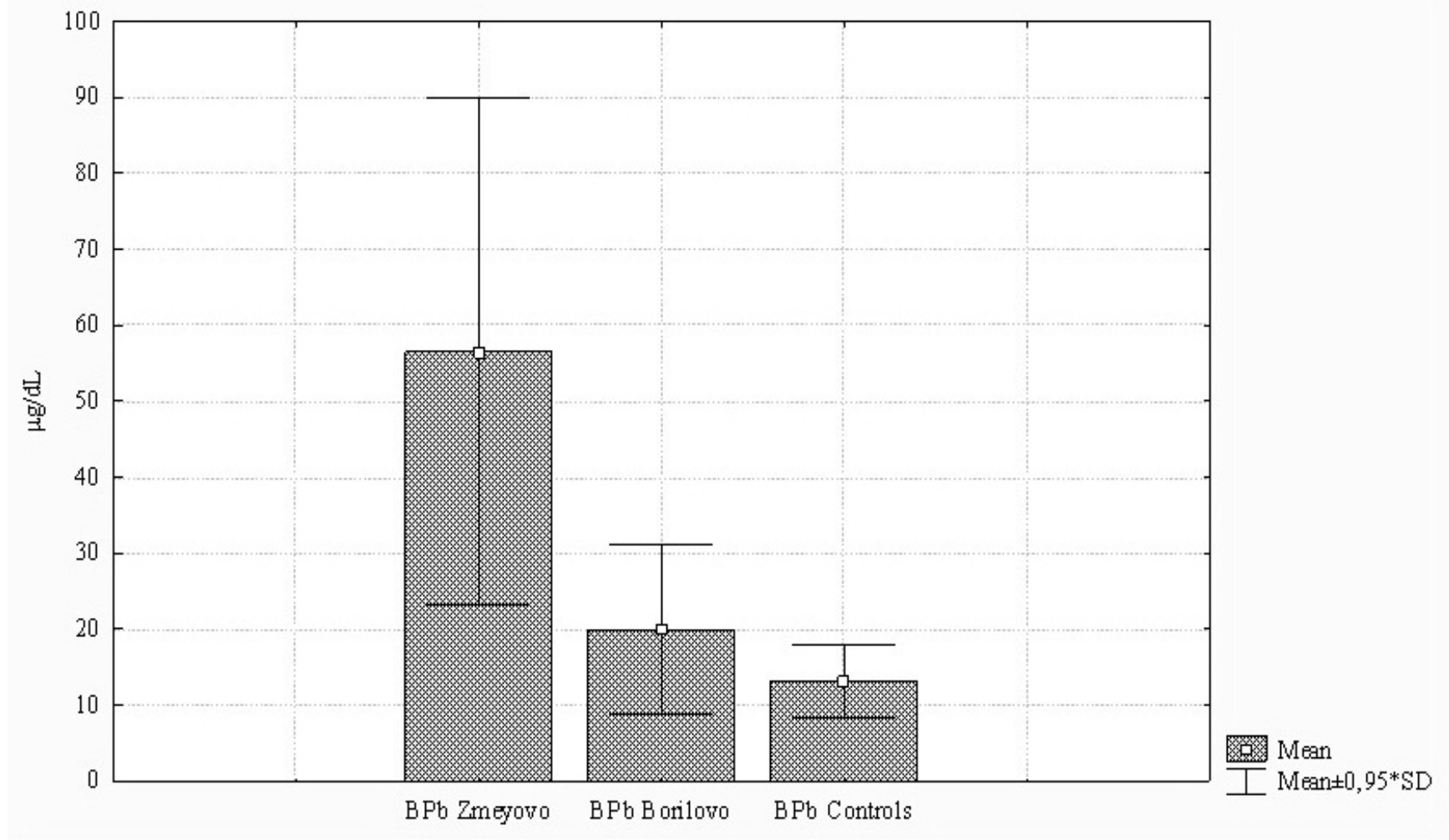

Figure 1. Mean blood lead levels $(\mathrm{BPb})$

Statistically significant differences: Zmeyovo-Controls ( $p=0.00003)$;

Borilovo-Controls ( $p<0.05)$; Zmeyovo-Borilovo $(p<0.0003)$.

The significantly highest mean blood cadmium level (BCd) was also assessed for the test group from Zmeyovo $(3.36 \pm 2.2 \mu \mathrm{g} / \mathrm{L})$, compared to the group from Borilovo $(0.95 \pm 0.69 \mu \mathrm{g} / \mathrm{L})$ and to the control group $(0.53 \pm 0.45 \mu \mathrm{g} / \mathrm{L})$. Mean $\mathrm{BCd}$ for Borilovo was significantly higher than for the control village (Figure 2). Donors with $\mathrm{BCds}$ above $2 \mu \mathrm{g} / \mathrm{L}$ in Zmeyovo were seven out of nine women and six out of eight men. Measured $\mathrm{BCds}$ in five women from Zmeyovo were even higher than $5 \mu \mathrm{g} / \mathrm{L}$. Only one woman from
Borilovo showed BCd level over $2 \mu \mathrm{g} / \mathrm{L}$; the same person had the highest $\mathrm{BPb}$ level in her group.

The mean blood nickel level (BNi) was significantly higher in Zmeyovo - $2.17 \pm 0.77$ $\mu \mathrm{g} / \mathrm{L}$ compared to Borilovo and the control village, where mean $\mathrm{BNis}$ were almost identical - $1.32 \pm 0.95 \mu \mathrm{g} / \mathrm{L}$ and $1.33 \pm 1.11 \mu \mathrm{g} / \mathrm{L}$, respectively (Figure 3). 


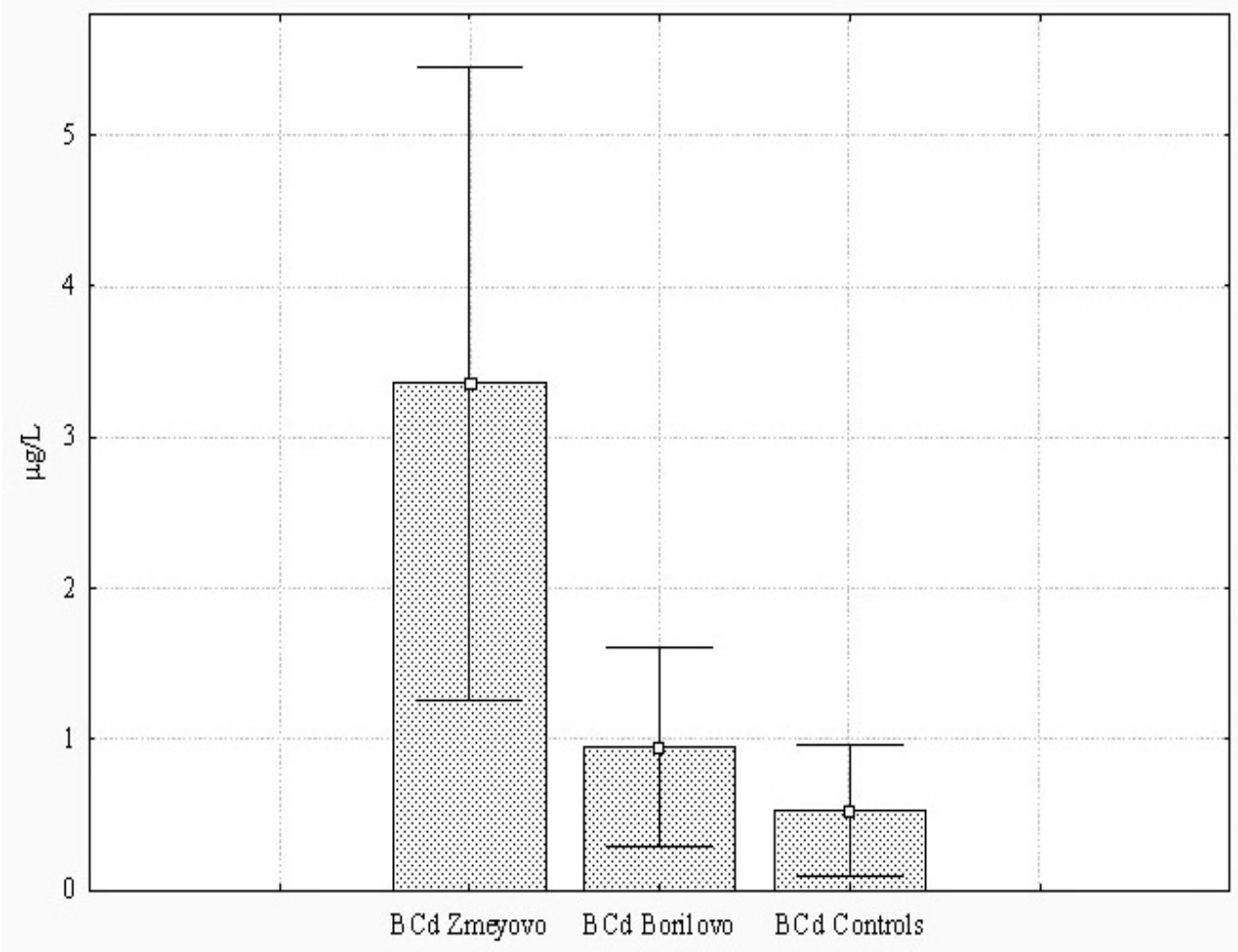

Mean

Mean $\pm 0,95^{*} \mathrm{SD}$

Figure 2. Mean blood cadmium levels (BCd)

Statistically significant differences: Zmeyovo-Controls $(p=0.00002)$;

Borilovo-Controls ( $p<0.05)$; Zmeyovo-Borilovo $(p<0.0002)$.

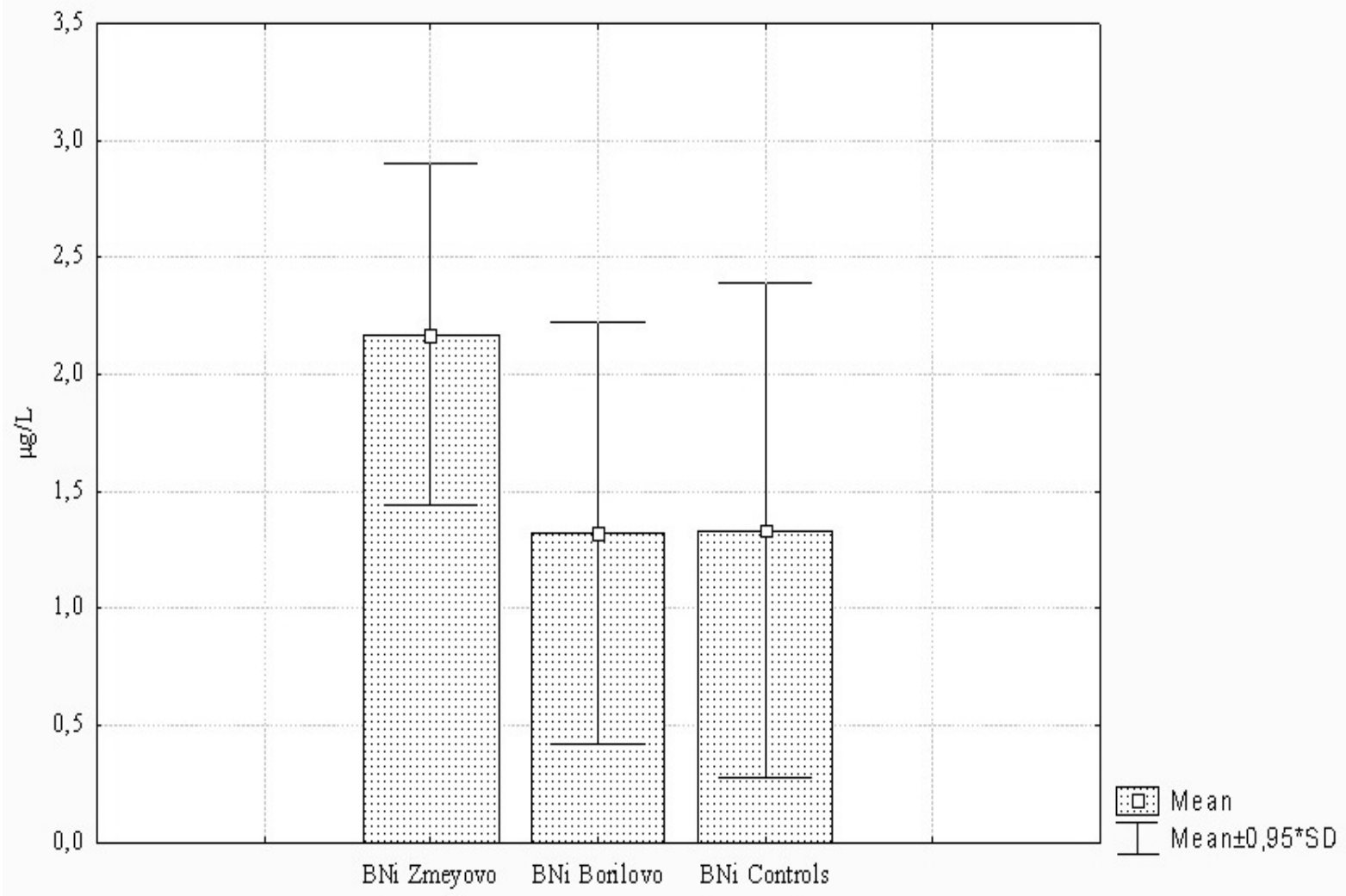

Figure 3. Mean blood nickel levels (BNi)

Statistically significant differences: Zmeyovo-Controls ( $p<0.02)$;

Zmeyovo-Borilovo $(p<0.01)$. 
No significant difference in blood concentrations for all of the investigated heavy metals was found between the men and women in the study. A statistically significant correlation was found between $\mathrm{BPb}$ and $\mathrm{BCd}$ levels among the studied donors $\quad(r=0.46 ; \quad p=0.0009)$. Significant correlation was also observed between lead and nickel $(\mathrm{r}=0.37 ; \mathrm{p}=0.0086)$, and cadmium and nickel blood levels $(\mathrm{r}=0.41 ; \mathrm{p}=0.0035)$ among the studied villagers.

\section{DISCUSION}

Measured mean blood lead levels in residents of Zmeyovo and Borilovo were higher than the control group's, as well as much higher than $\mathrm{BPbs}$ in adults with no history of occupational lead exposure, as reported by other authors:

- Hernandez-Avila et al. in Mexico - 11.9 $\mu \mathrm{g} / \mathrm{dL}$ for environmentally exposed adults (23);

- Chen et al. in China - 13.2 $\mu \mathrm{g} / \mathrm{dL}$ for men and $10.1 \mu \mathrm{g} / \mathrm{dL}$ for women (24);

- Apostoli et al. in Italy $-4.51 \mu \mathrm{g} / \mathrm{dL}$ for men and $3.06 \mu \mathrm{g} / \mathrm{dL}$ for women (22);

- Forte et al. in Sardinia - $4.12 \mu \mathrm{g} / \mathrm{dL}$ (GM) for the general population over 60 years of age (25).

Cheng et al. studied blood lead levels in middle aged and elderly men (mean age 67 years) in the United States and found a mean $\mathrm{BPb}$ of 6.2 $\mu \mathrm{g} / \mathrm{dL}$ not adjusted for smoking habits, which is much lower than our results for similarly aged groups (26). The mean $\mathrm{BPb}$ for Zmeyovo was more than two times higher than the $20 \mu \mathrm{g} / \mathrm{dL}$ set as a threshold for low-level lead effect in adults (12), but adverse effects may be observed at even lower concentrations (11). Blood lead levels above $40 \mu \mathrm{g} / \mathrm{dL}$, found in ten residents of Zmeyovo are known to cause symptoms of mild lead intoxication - reduced hemoglobin levels and gastrointestinal disturbances (14), erythrocyte protoporphyrin elevation, peripheral nerve dysfunction, increased urinary $\delta$ aminolevulinic acid and elevated coproporphyrin (10).

Blood levels of cadmium in tested villagers, especially from Zmeyovo, were also comparatively higher than reported in environmental studies. Chia et al. examined 278 non-smokers in Singapore and found geometric mean BCd for men $0.21 \mu \mathrm{g} / \mathrm{L}$ and $0.26 \mu \mathrm{g} / \mathrm{L}$ for women (27). Khassouani et al. found a mean BCd for men $1.1 \pm 0.8 \mu \mathrm{g} / \mathrm{L}$, significantly higher than that in women $-0.8 \pm 0.4 \mu \mathrm{g} / \mathrm{L}$ (28). Forte et al. observed a $0.56 \mu \mathrm{g} / \mathrm{L}$ geometric mean $\mathrm{BCd}$ in residents of Sardinia aged above 60 years (25), and Björkman et al. reported a $0.41 \mu \mathrm{g} / \mathrm{L}$ geometric mean BCd for Swedish twins (18). All cited mean blood cadmium levels are lower than the mean BCd found in Zmeyovo donors. The US Center for Disease Control and Prevention gives reference levels of $0.4 \mu \mathrm{g} / \mathrm{L}$ for blood cadmium in non-exposed non-smokers in the United States (29). Long-term exposure to cadmium with a blood concentration over $2 \mu \mathrm{g} / \mathrm{L}$ could lead to renal tubular dysfunction manifested with $\beta 2$-microglobulinuria. Serious health damage may occur for BCd above $5 \mu \mathrm{g} / \mathrm{L}$ $(30,31)$. Among all examined individuals, BCds above $5 \mu \mathrm{g} / \mathrm{L}$ were registered in four women from Zmeyovo, which might necessitate a microglobulin measurement in urine for Zmeyovo villagers.

Measured concentrations of nickel in blood for all tested groups were relatively high. Serum concentrations above $1.0 \mu \mathrm{g} / \mathrm{L}$ of nickel probably indicate a chronically excessive intake of nickel (12). Stojanovic et al. studied 123 non-exposed subjects and reported blood nickel levels ranging from 0.01-0.42 $\mu \mathrm{g} / \mathrm{L}$ without a significant difference between smokers and non-smokers much lower than the mean $\mathrm{BNi}$ in residents from all studied villages (21). Ibeto and Okoye observed a mean BNi of $0.124 \mathrm{ppm}$ in Nigerian urban population (32). The much higher blood concentrations of nickel revealed in the current study pose a health risk, especially for the residents of Zmeyovo.

Blood concentrations for the three studied metals (lead, cadmium and nickel) in the test villages Zmeyovo and Borilovo were higher compared to existing data on those concentrations in the general population of other countries. A possible cause could be the presence of persistent heavy metal pollutants in the environment and their inclusion in the food chain. On the other hand, high blood heavy metal concentrations might be a result of reentry from tissue stores. Gulson et al. proposed that between $45 \%$ and $70 \%$ of lead in the blood is accumulated from long-term tissue lead stores rather than the contemporaneous environment (33). Therefore, current low levels of heavy metals in the air, drinking water and soil do not eliminate the possibility of significant accumulation in the body.

The highest blood heavy metal levels among the residents of Zmeyovo could be explained with the close presence of air pollution sources - two 
military testing facilities $(2 \mathrm{~km}$ east and west of the village, respectively) and a major road. Another explanation might be the consumed food, since food constitutes the main route of exposure to heavy metals for non-smokers. The studied population consists mainly of retired village residents with low incomes, who usually produce most of their plant- and animal-based food. It is also known that deficiencies in protective micronutrients like calcium, iron and vitamin $\mathrm{C}$ in the diet are associated with increased resorption of heavy metals $(12,23,24$, 26).

No difference was observed between heavy metals blood concentrations in men and women. This find corresponds to data reported by Olsson et al., who compared cadmium blood and urine concentrations in non-smoking men and women from rural areas in southern Sweden (34). Khassouani et al. reported similar findings in France (28). Some authors reported significantly higher blood levels in males than in females for lead and cadmium (35), cadmium (28), lead (36), and nickel (32), while others found higher blood levels in women for $\mathrm{BCd}$ among non-smokers $(18,37)$. Evidently, gender is only one of many factors influencing blood heavy metal concentrations.

The correlations observed between blood concentrations of lead, cadmium and nickel suggest combined exposure. Such simultaneous exposure to lead and cadmium in heavily industrialized regions is not exceptional. Similar associations were observed by Björkman et al. in non-smoking Swedish twins, and the authors concluded that only environmental influences could have contributed to the association (18).

Blood heavy metal levels measured among the studied villagers showed a continuous exposure, with consumed food as the possible source. Therefore, it is advisable to monitor heavy metal levels in garden soil, and in foodstuffs and homemade beverages typical for the villagers' diet. Root vegetables, leafy greens, cereals, milk products, meat and offal (liver, kidney) have to be investigated with priority, since these foods are associated with greater heavy metal contamination $(11,24,38)$. Blood concentrations exceeding recommended levels in some studied individuals necessitate the measuring of biomarkers for heavy metal effects (increased $\delta$ aminolevulinic acid, reduced hemoglobin levels, $\beta 2$-microglobulinuria, proteinuria, etc.). Biomarker monitoring is also needed because of the synergistic harmful effect of lead and cadmium on the renal function and the observed correlation between their blood levels. Additionally, more village residents from Zmeyovo and Borilovo, especially children, should undergo screen tests for heavy metal exposure.

In conclusion, the measured blood concentrations of lead, cadmium, and nickel in village population (Zmeyovo, Borilovo) from Stara Zagora region indicate long-term environmental pollution in the area and an increased health risk. Probably the most prominent sources of exposure are plant and animal foods, grown and raised by the villagers themselves. Therefore, a more comprehensive investigation of the heavy metal content of regularly consumed foods should be performed. It is also reasonable to assess biomarkers of effect corresponding to the elevated blood heavy metal concentrations among residents of Zmeyovo. An important measure could be the implementation of screening programs for the village and urban population of Stara Zagora municipality, especially for children and young adults.

\section{ACKNOWLEDGEMENTS}

This study was supported by a grant (15/2012) from the Faculty of Medicine, Trakia University, Bulgaria. The authors wish to thank all participating village residents and the mayors of Stara Zagora Municipality and of Zmeyovo for their cooperation and support.

\section{REFERENCES}

1. Clean Air Act (Закон за чистотата на атмосферния въздух). Bulgarian State Gazette, 45, May 28, 1996.

2. National Report on the State and Protection of the Environment. Ministry of Environment and Water of Bulgaria, Executive Environment Agency, Sofia, Bulgaria, 2014.

3. Ordinance № 11 on the norms of arsenic, cadmium, nickel and polycyclic hydrocarbons in air (Наредба № 11 за норми за арсен, кадмий, никел и полициклични ароматни въглеводороди в атмосферния въздух). Bulgarian State Gazette, 42, May 29, 2007.

4. Ordinance № 12 on the norms of sulphur dioxide, nitrogen dioxide, particulate matter, lead, benzene, carbon monoxide and ozone in the atmosphere (Наредба № 12 за норми за серен диоксид, азотен диоксид, фини 
прахови частици, олово, бензен, въглероден оксид и озон в атмосферния въздух). Bulgarian State Gazette, 58, July 30, 2010.

5. Ordinance № 9 of the quality of water intended for drinking purposes (Наредба № 9 за качеството на водата, предназначена за питейно-битови цели). Bulgarian State Gazette, 30, March 28, 2001.

6. Ordinance № 5 for setting the maximum levels for certain contaminants in foodstuffs (Наредба № 5 за определяне на максимално допустимите количества на някои замърсители в храните). Bulgarian State Gazette, 14, February 20, 2015

7. Gradeva, H., Sandeva, G., Gidikova, P., Platikanova, M., Deliradeva, R., Prakova, G., Atanasov. V., Heavy metals in plants, soil and water from Stara Zagora region: defining locations for population exposure measurements. Trakia Journal of Sciences, 10(3):125-129, 2012.

8. Ordinance № 3 on the limit values for harmful substances in soil (Наредба № 3 за нормите за допустимо съдържание на вредни вещества в почвите). Bulgarian State Gazette, 71, August 12, 2008.

9. Ordinance № 1 on the research, use and protection of groundwater (Наредба № 1 за проучване, ползване и опазване на подземните води). Bulgarian State Gazette, 87, October 30, 2007.

10. World Health Organization. Air Quality Guidelines for Europe. $2^{\text {nd }}$ ed. $W H O$, Copenhagen, Denmark, 2000.

11. World Health Organization. Health risks of heavy metals from long-range transboundary air pollution. WHO, Copenhagen, Denmark, 2007.

12. World Health Organization. Trace elements in human nutrition and health. WHO, Geneva, Switzerland, 1996.

13. Bull, S., Foxall K., HPA Compendium of Chemical Hazards - Nickel. Version 1. HPA, UK, 2008.

14. Bull, S., HPA Compendium of Chemical Hazards - Lead. Version 2. HPA, UK, 2011.

15. Bull, S., HPA Compendium of Chemical Hazards - Cadmium. Version 5. HPA, UK, 2011.

16. Pizzol, M., Thomsen, M., Andersen, M.S., Long-term human exposure to lead from different media and intake pathways. Sci Total Environ, 408(22):5478-5488, 2012.
17. Järup, L., Hazards of heavy metal contamination. Br Med Bull, 68:167-182, 2003.

18. Björkman, L., Vahter, M., Pedersen, N.L., Both the environment and genes are important for concentrations of cadmium and lead in blood. Environ Health Perspect, 108(8):719-722, 2000.

19. Templeton, D.M., Sunderman, F.W., Herber, R.F.M., Tentative reference values for nickel concentrations in human serum, plasma, blood, and urine: evaluation according to the TRACY protocol. Sci Total Environ, 148(23):243-251, 1994.

20. Kim, M. and Kim, K., Biomonitoring of lead and cadmium in the hair and fingernails of elderly Korean subjects. Biol Trace Elem Res, 143(2):794-802, 2011.

21. Stojanović, D., Nikić, D., Lazarević, K., The level of nickel in smoker's blood and urine. Cent Eur J Public Health, 12(4):187-189, 2004.

22. Apostoli, P., Baj, A., Bavazzano, P., Ganzi, A., Neri, G., Ronchi, A., Soleo, L., Di, L.L., Spinelli, P., Valente, T., Minoia, C., Blood lead reference values: the results of an Italian polycentric study. Sci Total Environ, 287(12):1-11, 2002.

23. Hernández-Avila, M., Smith, D., Meneses, F., Sanin, L.H., Hu, H., The influence of bone and blood lead on plasma lead levels in environmentally exposed adults. Environ Health Perspect, 106(8):473-477, 1998.

24. Chen, C., Wang, X., Chen, D., Li, G., Ronnenberg, A., Watanabe, H., Wang, X., Ryan, L., Christiani, D.C., Xu, X., Tofu consumption and blood lead levels in young Chinese adults. Am J Epidemiol, 153(12):1206-1212, 2001.

25. Forte, G., Madeddu, R., Tolu, P., Asara, Y., Marchal, J.A., Bocca, B., Reference intervals for blood $\mathrm{Cd}$ and $\mathrm{Pb}$ in the general population of Sardinia (Italy). Int J Hyg Envir Heal, 214:102-109, 2001.

26. Cheng, Y., Willett, W.C., Schwartz, J., Sparrow, D., Weiss, S., Hu, H., Relation of nutrition to bone lead and blood lead levels in middle-aged to elderly men. Am J Epidemiol, 147(12):1162-1174, 2001.

27. Chia, S.E., Chan, O.Y., Sam, C.T., Heng, B.H., Blood cadmium levels in nonoccupationally exposed adult subjects in Singapore. Sci Total Environ, 145(1-2):119123, 1994.

28. Khassouani, C.E., Soulaymani, R., Mauras, Y., Allain, P., Blood cadmium concentration 
in the population of the Rabat area, Morocco. Clinica Chimica Acta, 302(12):155-160, 2000.

29. Centers for Disease Control and Prevention. Third National Report on Human Exposure to Environmental Chemicals. $C D C$, Atlanta, USA, 2005.

30. Boonprasert, K., Kongjam, P., Limpatanachote, P., Ruengweerayut, R., NaBangchang, K., Urinary and blood cadmium levels in relation to types of food and water intake and smoking status in a Thai population residing in cadmiumcontaminated areas in Mae Sot. Southeast Asian J Trop Med Public Health, 42(6):1521-1530, 2011.

31. Agency for Toxic Substances and Disease Registry. Case Studies in Environmental Medicine (CSEM) - Cadmium Toxicity. The Agency, Atlanta, USA, 2008.

32. Ibeto, C.N., Okoye, C.O.B., High levels of heavy metals in blood of the urban population of Nigeria. Research Journal of Environmental Sciences, 4(4):371-382, 2010.

33. Gulson, B.L., Mahaffey, K.R., Mizon, K.J., Korsch, M.J., Cameron, M.A., Vimpani, G., Contribution of tissue lead to blood lead in adult female subjects based on stable lead isotope methods. $J$ Lab Clin Med, 125(6):703-712, 1995.

34. Olsson, I.M., Bensryd, I., Lundh, T., Ottosson, H., Skerfving, S., Oskarsson, A., Cadmium in blood and urine - impact of sex, age, dietary intake, iron status, and former smoking - association of renal effects. Environ Health Perspect, 110(12):11851190, 2002.

35. Sirivarasai, J., Kaojaren, S., Wananukul, W., Srisomerang, P., Non-occupational determinants of cadmium and lead in blood and urine among a general population in Thailand. Southeast Asian J Trop Med Public Health, 33(1):180-187, 2002.

36. Bushnik, T., Haines, D., Levallois, P., Levesque, J., Van Oostdam, J., Viau, C., Lead and bisphenol A concentrations in the Canadian population. Health Reports, 21(3):1-12, 2010.

37. Watanabe, T., Koizumi, A., Fujita, H., Kumai, M., Ikeda, M., Cadmium levels in the blood of inhabitants in nonpolluted areas in Japan with special references to aging and smoking. Environ Res, 31(2):472-483, 1983.

38. De Winter-Sorkina, R., Bakker, M.I., van Donkersgoed, G., van Klaveren, J.D., Dietary intake of heavy metals (cadmium, lead and mercury) by the Dutch population. RIVM, Bilthoven, The Netherlands, 2003. 